\title{
Genentech wins round two
}

\section{Washington}

GENENTECH, the biotechnology company based in South San Francisco, gained a victory in its long-running battles with the UK-based Wellcome Foundation and Genetics Institute of Massachusetts when a jury in a district court in Delaware ruled last week that three of its key patents for the blood-clot dissolving agent tissue plasminogen activator (TPA) had been infringed.

The court case is almost a re-run of the action brought by Genentech in 1987 to prevent Wellcome from infringing on its TPA patents in the United Kingdom (see Nature 328, 189; 1987). The outcome was, however, quite different, as the British High Court declared Genentech's wideranging TPA patents to be invalid. Genentech appealed, but the decision was upheld in the British Appeal Court. The outcome of these quite separate court actions outlines the dissimilarity between

\section{AWARDS}

\section{Australia's new prize}

\section{Sydney}

The Australia Prize, a new international science prize worth $A \$ 250,000$, has been awarded to Eugene Nester of the University of Washington in Seattle, Jeff Schell of the Max Planck Institute and Allen Kerr of the White Agricultural Research Institute in Adelaide for their work on crown gall disease.

The prize was created as part of an initiative by Barry Jones, until recently the Minister of Science, to raise the profile of science in Australia. It will be awarded in a different area of science each year and only those who have not already received a leading award in the nominated field will be eligible to receive it.

The 1990 Australia Prize was awarded for excellence in the field of biological sciences related to agriculture and the environment. Crown gall disease is responsible for annual losses of $\mathrm{A} \$ 100$ million in damage to crops worldwide.

Kerr isolated the bacterium, Agrobacterium tumefaciens, responsible for crown gall disease. Nester and Schell have studied the way in which the organism causes the disease and have developed a genetically engineered benign strain of the bacterium.

Although the prize was established to boost the prestige of science, it has not been popular with the Australian scientific community. The administrative costs of the prize came to $A \$ 160,000$ in its first year of operation and despite assurances from the government that this money would not come out of the science budget, many scientists feel that support for research would have been preferable to support for a prize.

Tania Ewing
US and UK biotechnology patent law. It is like comparing "apples and oranges", says Susan Rogers of Genentech.

The Delaware action is seen as an attempt by Genentech to stave off the competition from Duteplase, Genetics Institute's version of TPA that is licensed to Wellcome, as well as other 'secondgeneration' TPAs now under development. Wellcome is currently awaiting approval of Duteplase by the US Food and Drug Administration.

Although the judge has not entered a final ruling on the jury's decision, Genentech's president and chief executive officer, G. Kirk Raab was quick to claim that "this verdict is a major victory for the biotechnology industry because it signals that such patents will provide meaningful protection for biotechnology innovations".

The action against Wellcome and Genetics Institute was brought by Genentech and was countered by Wellcome's antitrust action and Genetics Institute's claims of unfair competition. The jury ruled that both these claims were without merit. Although the jury upheld the validity of the three patents, no monetary damages were awarded to Genentech. Wellcome spokesman Martin Sherwood would not comment on the jury's decision until the judge has entered a final ruling.

Genentech's TPA, marketed under the trade name Activase, is the only form of TPA approved for sale in the United States for the treatment of heart attacks. In 1989, sales of TPA reached $\$ 196.6$ million, an increase of 30 per cent on the previous year. It is estimated that the worldwide market for thrombolytic agents will reach $\$ 500$ million by 1993 . Susan Rogers, a spokeswoman for Genentech, says that Genentech will be filing an injunction against the two companies to prevent them from marketing Duteplase in the United States. At this stage, it is unclear how this decision will affect the 'second-generation' TPAs such as novel plasminogen activator, which Genetics Institute licensed to Burroughs Wellcome, the US subsidiary of Wellcome, in December 1989. The drug is in the preclinical phase of development and is a modified form of TPA with deleted fibronectin and epidermal growth factor domains and changes to the glycosylation sites. It is hoped that this modified form of TPA will have a longer half-life in the bloodstream than TPA so that it can be given as a bolus injection over a shorter period of time.

The Delaware court's decision will provide a welcome boost to Genentech, which is fighting to hold on to two-thirds of the US market share. Last month, results of an Italian direct clinical trial between TPA and streptokinase (Hoechst-

\section{Hopes of better times}

\section{São Paulo}

ThE Brazilian Congress has turned into law a provisional measure reducing restrictions on the import of scientific equipment and laboratory materials. The measure was among the last issued by the government of ex-President José Sarney and was strongly supported by scientists.

The new law was unanimously approved by all parties. There was a last-minute threat when one senator wanted to bar the import of equipment when a Brazilian 'alternative' existed. But lobbying defeated the amendment on the grounds that it would have continued the practice of forcing scientists to buy Brazilian regardless of quality.

The new secretary of Science and Technology, physicist José Goldemberg, also announced recently that he is negotiating loans from the World Bank and from the Inter-American Development Bank to help science and technology projects. Goldemberg is thought to be asking for $\$ 400$ million.

Nobel prizewinning physicist Abdus Salam is also trying to encourage Brazil to spend more on science. Salam, who is head of the International Centre for Theoretical Physics at Trieste and has been active in encouraging international banks to help developing countries to invest in science, last month wrote to Brazil's new president, Fernando Collor de Mello, saying that Brazil's investment in science is too low given the size of its economy. Brazil spends roughly 0.7 per cent of its gross domestic product on science and technology.

Goldemberger wants to try to double that figure by the end of Collor's five-year term. But the previous president's science ministers set a goal of 2 per cent - and failed.

Ricardo Bonalume

Roussel Pharmaceuticals) showed that TPA is no more effective than streptokinase, which is one-tenth of the price and the preferred drug in Europe (see Nature 344, 183; 15 March 1990). In addition, Genentech is having to fend off new competition from SmithKline Beecham's Eminase, which has a longer half-life than TPA and can therefore be administered as a bolus injection over 2-5 minutes, instead of being infused over a 3-hour period as in the case of TPA.

Stewart Adkins, stock analyst for Shearson Lehman Hutton in the United Kingdom, believes that Duteplase is not going to be particularly important for Wellcome, which is better known for the AIDS drug, AZT. In view of the fact that aspirin and streptokinase is a cheap combination and that the mortality data are favourable, he feels that there is not a lot of money to be made in the thrombolytic market and the likelihood of making a return on investment is diminishing.

Diane Gershon 